\title{
Sea star wasting disease pathology in Pisaster ochraceus shows a basal-to-surface process affecting color phenotypes differently
}

\author{
Thierry M. Work ${ }^{1, *}$, Tina M. Weatherby ${ }^{2}$, Christopher M. DeRito $^{3}$, \\ Ryan M. Besemer ${ }^{3,4}$, Ian Hewson ${ }^{3}$
}

\begin{abstract}
${ }^{1}$ US Geological Survey, National Wildlife Health Center, Honolulu Field Station, Honolulu, HI 96850, USA ${ }^{2}$ University of Hawaii, Pacific Biosciences Research Center, Biological Electron Microscope Facility, Honolulu, HI 96822, USA ${ }^{3}$ Cornell University, Department of Microbiology, Ithaca, NY 14853, USA

${ }^{4}$ University of North Carolina, Wilmington, NC 28403, USA
\end{abstract}

\begin{abstract}
Sea star wasting disease (SSWD) refers to a suite of poorly described non-specific clinical signs including abnormal posture, epidermal ulceration, and limb autotomy (sloughing) causing mortalities of over 20 species of sea stars and subsequent ecological shifts throughout the northeastern Pacific. While SSWD is widely assumed to be infectious, with environmental conditions facilitating disease progression, few data exist on cellular changes associated with the disease. This is unfortunate, because such observations could inform mechanisms of disease pathogenesis and host susceptibility. Here, we replicated SSWD by exposing captive Pisaster ochraceus to a suite of non-infectious organic substances and show that development of gross lesions is a basal-to-surface process involving inflammation (e.g. infiltration of coelomocytes) of ossicles and mutable collagenous tissue, leading to epidermal ulceration. Affected sea stars also manifest increases in a heretofore undocumented coelomocyte type, spindle cells, that might be a useful marker of inflammation in this species. Finally, compared to purple morphs, orange $P$. ochraceus developed more severe lesions but survived longer. Longer-lived, and presumably more visible, severely-lesioned orange sea stars could have important demographic implications in terms of detectability of lesioned animals in the wild and measures of apparent prevalence of disease.
\end{abstract}

KEY WORDS: Echinoderm $\cdot$ Clinical pathology $\cdot$ Histopathology $\cdot$ Light microscopy $\cdot$ Electron microscopy

\section{INTRODUCTION}

Sea star wasting disease (SSWD) in Asteroidea (Echinodermata) manifests as variable degrees of abnormal posture, epidermal ulceration, autotomy (sloughing) of rays, or eversion of viscera through the body wall that often leads to death (Hewson et al. 2014). SSWD affects over 20 species of sea stars in the northeastern Pacific and has caused intermittent mass mortality since 2013, leading to large shifts in ecosystem structure (Schultz et al. 2016, Miner et al. 2018, Jaffe et al. 2019, Konar et al. 2019) and functional extirpation of some species like Pycnopodia

\footnotetext{
*Corresponding author: thierry_work@usgs.gov
}

helianthoides (Montecino-Latorre et al. 2016, Jaffe et al. 2019). SSWD was initially thought to be caused by a densovirus (Hewson et al. 2014) based on molecular evidence of virus in affected animals and an apparent ability to transmit disease using cell-free filtrates that lost activity after heat treatment. However, later studies failed to confirm this hypothesis (Hewson et al. 2018, 2020, Jackson et al. 2020b), and the widespread presence of densoviruses in apparently healthy sea stars (Jackson et al. 2020a) argues against densoviruses as a cause of SSWD.

Indeed, challenges with filtered $(<0.2 \mu \mathrm{m})$ tissue homogenates (Hewson et al. 2014) do not exclusively

(C) T. Weatherby, C. DeRito, R. Besemer, I. Hewson and, outside the USA, the US Government 2021. Open Access under Creative Commons by Attribution Licence. Use, distribution and reproduction are unrestricted. Authors and original publication must be credited. Publisher: Inter-Research · www.int-res.com 
point to viruses as candidate etiological agents of SSWD. For instance, arm autotomy in echinoderms is a physiological process in part mediated by sea star proteins and neurotransmitters affecting stiffness of mutable collagenous tissue (MCT), and autotomy can be reproduced by injecting fluids from sea stars undergoing autotomy into normal sea stars (Yamada et al. 2010, Motokawa 2011). Inability to replicate disease using heat-treated filterable extracts from SSWD-affected sea stars (Hewson et al. 2018) could be explained by heat denaturing and inactivation of sea star proteins that mediate stiffness of MCT. So while SSWD is widely assumed to be infectious (Aalto et al. 2020), a non-infectious cause is equally plausible (Aquino et al. 2021). Temperature anomalies (Eisenlord et al. 2016, Kohl et al. 2016, Menge et al. 2016, Aalto et al. 2020), meteorological conditions (Hewson et al. 2018), and seawater $p \mathrm{CO}_{2}$ concentration (Menge et al. 2016) are hypothesized environmental drivers of SSWD disease outbreaks. Finally, the epidemiology of SSWD (a multitude of vastly different asteroid species affected across a broad geographic range) does not seem to support an infectious etiology by densovirus, a DNA virus. Most viruses with broad host ranges are RNA viruses (Bandín \& Dopazo 2011). A study of RNA viruses during wasting progression did not yield any genotype associated with lesion margins that could not also be found in scar tissue or grossly normal tissue, or any genotype that was consistent between wasting specimens (Hewson et al. 2020).

While much effort has gone into understanding potential environmental drivers of SSWD (see citations above), there is a lack of a clear case definition of SSWD based on gross and microscopic morphology. Most descriptions of the disease are based on gross lesions which present as a non-specific constellation of clinical signs ranging from focal epidermal ulceration to complete limb autotomy and eversion of gonads through the body wall (Hewson et al. 2014). Our knowledge of the underlying tissue changes associated with lesions of SSWD at the cellular level is limited. For instance, no histology showing convincing cellular pathology associated with viruses was presented in the original description of SSWD (Hewson et al. 2014). While centrifuged tissue homogenates contained viral-like particles compatible in morphology with densovirus, no data were presented showing densoviruses directly associated with cell pathology using methods like transmission electron microscopy, in situ hybridization, or immunohistochemistry (Hewson et al. 2014, 2018). This is unfortunate, because understanding disease processes in marine invertebrates at the cellular level using histology can elucidate mechanistic processes and potential causes of cell death that lead to manifestations of gross clinical signs (Work \& Meteyer 2014). For instance, in the coral Montipora capitata, tissue loss that appears grossly similar has multiple potential etiologies that can be differentiated at the microscopic level (Work et al. 2012).

A number of studies have attempted to replicate SSWD in controlled environments (Bates et al. 2009, Hewson et al. 2014, 2018, Eisenlord et al. 2016, Kohl et al. 2016, Jaffe et al. 2019, Kay et al. 2019), but only one study (Bucci et al. 2017) presented histology findings. In that study, captive northwest Atlantic Asterias forbesi developed SSWD lesions which histologically comprised epidermal vacuolation and edema of connective tissue. Only 2 other studies mentioned sea star pathology, one involving Odontaster validus from South Georgia Island, Antarctica, that showed epidermal ulceration, manifesting microscopically as inflammation of MCT (Núñez-Pons et al. 2018), and one involving various species of sea stars from the North American Pacific coast mortality event in 2014 that showed epidermal ulceration and inflammation (Newton \& Smolowitz 2018).

Here, we took advantage of an experiment investigating the impacts of organic matter enrichment on genesis of SSWD in Pisaster ochraceus (Aquino et al. 2021), a species affected by SSWD throughout the Pacific coast of North America, to examine the tissue and hematological changes associated with disease. Specifically, the hypothesis of the experiment was that SSWD lesions could be reproduced by amending surfaces of sea stars with organic matter that would result in proliferation of microorganisms leading to subsequent anoxia near animal surfaces and generation of gross lesions of SSWD. The details of the experiment and microbial and metabolic results are presented elsewhere (Aquino et al. 2021). Our objective here was to document the pathology of experimentally reproduced SSWD lesions, including in specimens that formed lesions in the absence of external stimuli. We show that development of SSWD is a basal-to-surface process starting with inflammation of ossicles and MCT leading to gross clinical signs of epidermal ulceration. Moreover, sea stars manifest increases in a heretofore undescribed cell type in coelomic fluid, i.e. spindle cells, suggesting them as a potential cytological marker of systemic inflammation in this species. Finally, orange sea stars survive longer and develop more severe lesions than purple sea stars, which may affect interpretations of demographic patterns of SSWD in the field. 


\section{MATERIALS AND METHODS}

\subsection{Treatments and gross exams}

Samples for this study were collected during a concurrent study on the impacts of organic matter enrichment on asteroid wasting (Aquino et al. 2021) performed at Bodega Bay, California, USA, in JulyAugust 2019. Pisaster ochraceus $(n=20$; mean \pm SE mass $303 \pm 26 \mathrm{~g}$ ) were haphazardly collected from the field (Bodega Jetty; $38.3332^{\circ} \mathrm{N}, 123.0481^{\circ} \mathrm{W}$ ) and housed collectively in large (ca. $1400 \mathrm{l}$ at an approximate density of 0.02 sea stars $\mathrm{l}^{-1}$ ) flow-through indoor aquaria for $14 \mathrm{~d}$ prior to the start of experiments during which they had ad lib access to a variety of preferred prey (mussels, urchins, and barnacles). Because these animals are invertebrates, Institutional Animal Care and Use Committee (IACUC) approval was not required.

At the start of the experiment, 20 individual animals were placed into high-density polyethylene containers measuring $32 \times 20 \times 6 \mathrm{~cm}(3600 \mathrm{ml})$ perforated with $3 \mathrm{~mm}$ holes at a density of $\sim 4$ holes $\mathrm{cm}^{-2}$. Containers were placed in 4 flow-through $(60 \pm 15 \mathrm{ml}$ $\mathrm{s}^{-1}$ ) seawater tables. On Day 0, each of 5 sea stars received the following treatments, administered by applying $0.015 \mathrm{ml} \mathrm{g}^{-1}$ animal $(\sim 3-11 \mathrm{ml})$ with a $3 \mathrm{ml}$ syringe on the surface of the animal's epidermis, the following organic materials: peptone (300 $\mathrm{mg}$ ind $\left.\mathrm{.}^{-1}\right)$, approx. $10^{5}$ cells of the cultured microalga Dunaliella tertiolecta, and particulate organic matter $\left(\mathrm{POM}_{\text {; }}\right.$ $>0.2 \mu \mathrm{m}$ filtrate) from $120 \mathrm{ml}$ of seawater collected at Bodega Bay; 5 control sea stars received no treatment. These treatments were chosen because it was hypothesized that organic matter (OM), especially that originating from primary production, could result in SSWD signs by producing suboxic microzones through heterotrophic respiration near asteroid surfaces (Aquino et al. 2021). Peptone is a common component of marine bacterial culture media and selects for copiotrophic marine taxa (Moebus 1980). D. tertiolecta culture was used as a unicellular algal source of POM. Coastal POM was used to simulate enrich- ment by organic material $>0.2 \mu \mathrm{m}$, which includes phytoplankton, bacterioplankton, and suspended inorganic particulates. The 3 amendments therefore informed responses to a non-native OM (protein) source, non-native phytoplankton-derived OM, and OM native to the environment from which the specimens were collected. Animals were weighed at the start and end of the experiment. Each day, animals were photographed and subjectively scored (on a scale of 0-4) for severity of lesions as described by Bates et al. (2009) (Table 1, Fig. 1). Animals were further categorized by color (orange or purple). The experiment lasted $16 \mathrm{~d}$.

\subsection{Cytology of coelomic fluid}

Coelomic fluid was sampled from sea stars, and slides were made as described by Work et al. (2020b). Briefly, $100 \mu \mathrm{l}$ of coelomic fluid were drawn directly into $100 \mu \mathrm{l}$ of $10 \%$ formalin, and $100 \mu \mathrm{l}$ of the resulting mixture were placed into a cut $1 \mathrm{cc}$ syringe barrel affixed to a microscope slide (Moore 2017) (Superfrost, Thermo Fisher). The formalin killed the coelomocytes instantly, thereby preventing spread or distortion of coelomocytes that often occurs once out of the host (Boolootian \& Giese 1958), and the syringe barrel served to concentrate coelomocytes in a sufficiently small area for microscopic observation. Cells were then air dried, fixed in absolute methanol, and microscopically examined with Romanowsky stain for microscopic examination. A variety of terminologies exist to describe sea star coelomocytes. Based on described morphologies, we classified them as phagocytes (Pinsino et al. 2007) (Fig. 2A), spherulelike (Fig. 2B), stippled (cells with fine stippling in the cytoplasm) (Fig. 2C), vibratiles (Pinsino et al. 2007) (Fig. 2D), multinucleate (Sharlaimova et al. 2010) (Fig. 2E), and spindle-like cells (Ben Khadra et al. 2015a) (Fig. 2F-L). Because $>95 \%$ of sea star cells were phagocytes, it made little sense to enumerate individual cells to efficiently compare groups of animals. We therefore only enumerated multinucleate,

Table 1. Score categories for gross and microscopic lesions in Pisaster ochraceus. NA: not applicable

\begin{tabular}{|lll|}
\hline Score & Gross description & Histology description \\
\hline 0 & Normal turgor and no evident epidermal lesions & No lesion \\
1 & Lesions $<5 \mathrm{~mm}$ diameter on 1 ray & Mild: covering $<5 \%$ of microscope $(200 \times)$ field \\
2 & Lesions $<5 \mathrm{~mm}$ diameter on 2 or more rays & Moderate: covering $>5-30 \%$ of microscope field \\
3 & Lesions on all rays and central disk or lesion $\geq 5 \mathrm{~mm}$ diameter & Severe: covering $>30 \%$ of microscope field \\
4 & As in Score 3 with limb autotomy & NA \\
\hline
\end{tabular}




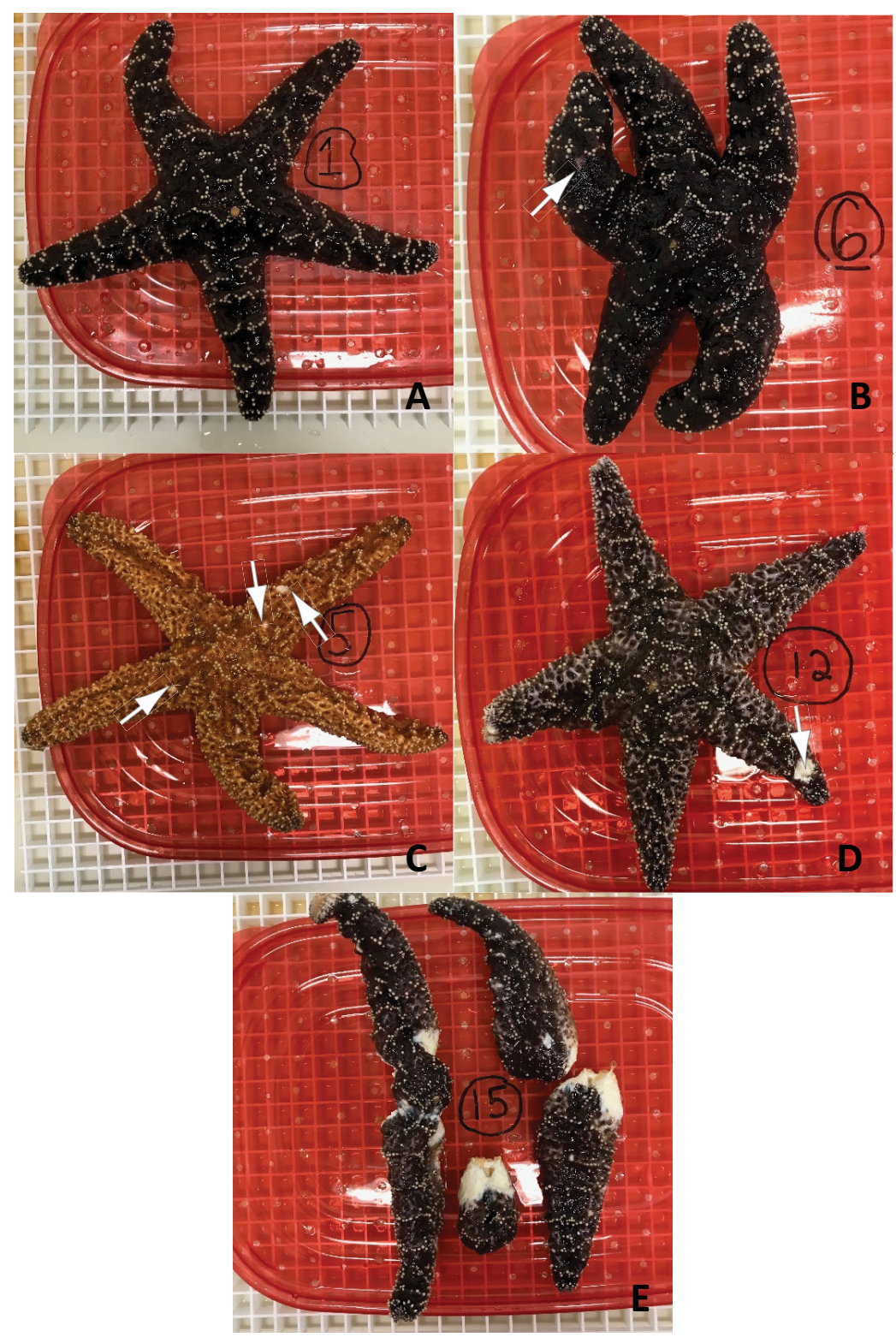

Fig. 1. Lesion severity scores in Pisaster ochraceus. (A) Score 0, purple morph. Note uniform coloration with normal pale stippling and eccentric madreporite. (B) Score 1, purple morph. Note single focal ulcer (arrow). (C) Score 2, orange morph. Note multiple ulcers (arrows) on multiple rays and prominent pale reticulation indicating thinning mutable collagenous tissue over ossicles. (D) Score 3, purple morph. Note prominent pale reticulation as in $\mathrm{C}$ and large ( $\geq 5 \mathrm{~mm}$ ) ulcer (arrow). (E) Score 4, purple morph. Note autotomy

pling regimen broadly followed that of biopsy sampling (see Section 2.3). Hematology slides were read by a single pathologist with no prior knowledge of the health status of the animals.

\subsection{Histology}

Tissues were biopsied using $4 \mathrm{~mm}$ sterile biopsy punches comprising epidermis and underlying MCT on the aboral surface or at lesion sites. At biopsy, tissues were classified as lesioned or apparently normal. Prior to histology processing, sections were decalcified in EDTA for $24 \mathrm{~h}$ to dissolve ossicles so as to allow sectioning on microtomes. After decalcification, tissues were processed with routine paraffin embedding, sectioning at $5 \mu \mathrm{m}$, and staining with hematoxylin and eosin or Masson trichrome (Prophet et al. 1992) to highlight MCT. Tissue changes at the microscopic level were graded (on a scale of 0-3) according to criteria outlined in Table 1. These included inflammation exemplified by infiltrates of coelomocytes, edema exemplified by increased spaces between collagen fibrils of MCT, necrosis comprising hyalinization, pyknosis, or karyorrhexis, ulceration of epidermis or lining of coelomic cavity, lysis of ossicles, epidermal atrophy, epidermal vacuolation, epidermal hyperplasia, vacuolation of basement membrane, cleft formation between epidermis and MCT, and increase or decrease of muriform cells as defined by epidermal cells with eosinophilic intracytoplasmic granules (Hyman 1955). Each sea star was then assigned a histology lesion score dependent on the number of lesions and

stippled, vibratile, spherule-like, and spindle cells in 20 oil-immersion $(1000 \times)$ microscope fields for each sea star. Coelomic fluid samples $(\mathrm{n}=75)$ were collected, comprising 20 each of peptone and POM, 18 Dunaliella, and 17 controls, collected on Day 0 ( $\mathrm{n}=$ 19), $1(\mathrm{n}=1), 3(\mathrm{n}=20), 4(\mathrm{n}=3), 5(\mathrm{n}=2), 6(\mathrm{n}=2), 7$ $(\mathrm{n}=1), 8(\mathrm{n}=1), 9(\mathrm{n}=3), 10(\mathrm{n}=2), 11(\mathrm{n}=1), 12(\mathrm{n}$ $=4), 13(\mathrm{n}=1), 14(\mathrm{n}=6)$, and $15(\mathrm{n}=9)$. This sam- their severity for the section examined (e.g. a sea star with 2 different lesion types, each severe, would have a total score of 6). Higher lesion scores indicate less healthy sea stars. Biopsies $(\mathrm{n}=52$ ) were collected comprising 11 controls, 13 POM controls, and 14 each of Dunalliela and peptone treatments sampled intermittently on Days $0(\mathrm{n}=12), 1$ $(\mathrm{n}=4), 3(\mathrm{n}=2), 4(\mathrm{n}=3), 5(\mathrm{n}=2), 6(\mathrm{n}=2), 7$ ( $\mathrm{n}=$ 


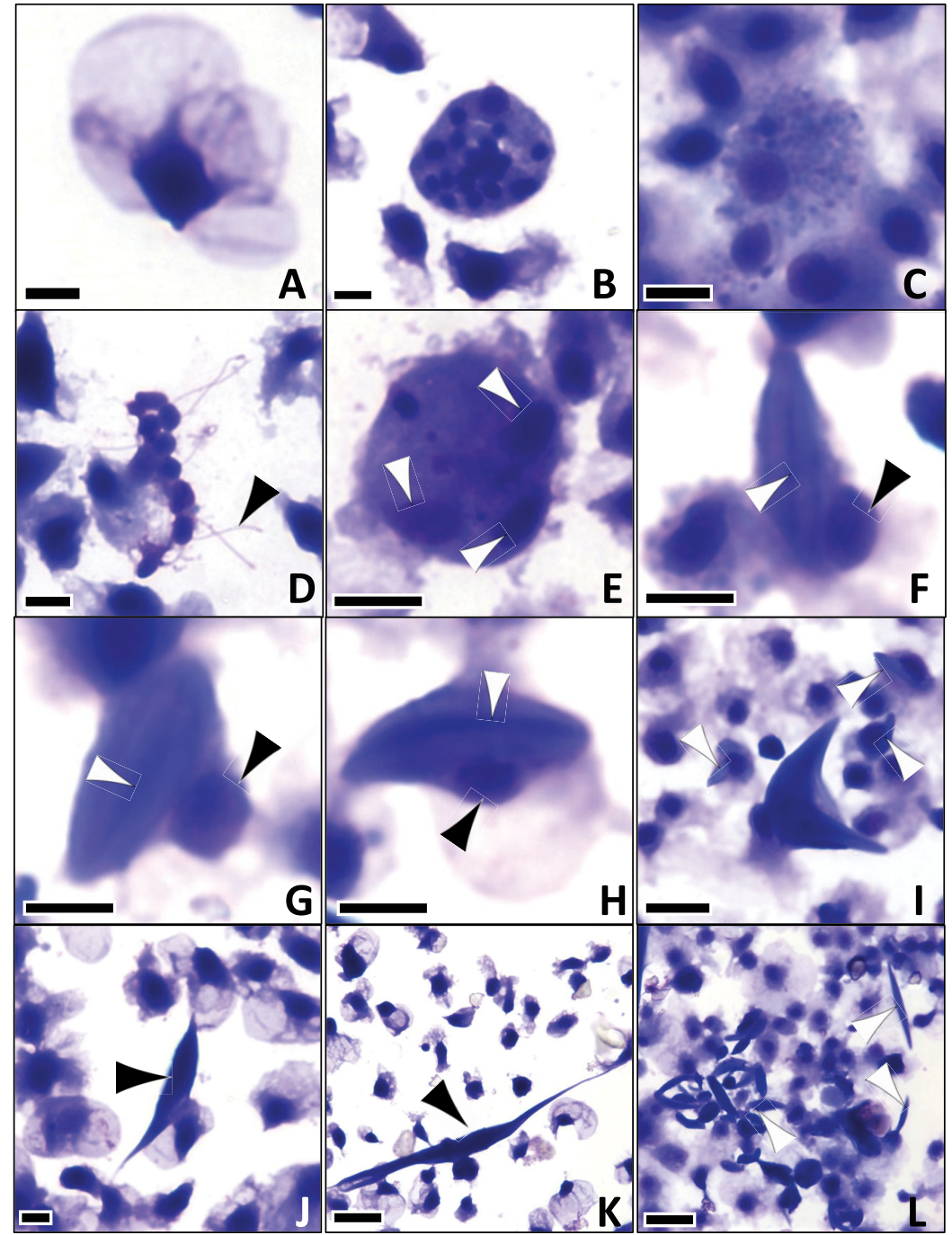

Fig. 2. Coelomocytes from Pisaster ochraceus; scale bar for all photos is $5 \mu \mathrm{m}$ except for panels I $(10 \mu \mathrm{m})$ and K-L $(20 \mu \mathrm{m})$. (A) Phagocyte; note pale blue petalloid cytoplasm surrounding angular nucleus. (B) Spherule cell; note blue cytoplasm surrounding central angular nucleus surrounded by variably sized dense blue granules. (C) Stippled cell; note pale cytoplasm enclosing numerous small granules and round nucleus. (D) Vibratile cells; note dense nucleus and flagellae (arrow). (E) Multinucleate cell; note dark blue cytoplasm and what appear to be multiple nuclei (arrows). ( $\mathrm{F}-\mathrm{H})$ Early-stage spindle cells; note lanceolate structure with central striation spanning poles of spindle (white arrow) with eccentric cell nucleus (black arrow). (I) Small to intermediate stage spindle cells; note bifurcate larger spindle (center) and smaller spindles apparently forming (white arrows). ( $\mathrm{J}, \mathrm{K})$ Mature large spindles; note broad deeply basophilic lanceolate structure with tapered tips (arrow).

(L) Spindles in clusters or isolated (arrows)

1), $8(\mathrm{n}=1), 9(\mathrm{n}=3), 10(\mathrm{n}=2), 11(\mathrm{n}=1), 12(\mathrm{n}=$ 4), $13(\mathrm{n}=1)$, and $14(\mathrm{n}=5), 15(\mathrm{n}=9)$. Aside from sampling on Day 0, timing of sampling of stars was done when new gross lesions arose on the animal. All histology slides were read by a single pathologist with no prior knowledge of the lesion status of the biopsy or the health status of the animal.

\subsection{Ossicles}

To ensure that changes in ossicles seen on histology were not an artefact of decalcification, we did scanning electron microscopy on ossicles of lesioned and normal sea stars. A section of the lateral ray (ca. $1-1.5 \mathrm{~cm}^{3}$ ) was cut from a fresh frozen $\left(-70^{\circ} \mathrm{C}\right)$ star using rongeurs, placed in $15 \mathrm{ml}$ conical tubes containing $10 \%$ bleach solution in artificial seawater (Instant Ocean) prepared according to the manufacturer's instructions, and placed on a rocker table for $24 \mathrm{~h}$ at room temperature to digest tissues away from calcified structures. Ossicles were then rinsed twice with tap water, once with $70 \%$ ethanol, and once with $90 \%$ ethanol, and then allowed to dry at $37^{\circ} \mathrm{C}$ for at least $3 \mathrm{~d}$. Ossicles were placed on adhesive-coated aluminum stubs, sputter-coated with gold/ palladium, and examined with a Hitachi S-4800 field emission scanning electron microscope. Two easily recognized morphologies of ossicles (those derived from pedicellariae, and sellate or saddle-shaped) were enumerated on the entire stub and scored subjectively as not (0), mildly (1), moderately (2), or severely eroded (3) (Fig. 3). This was done for 4 sea stars sampled at termination of the experiment, one for each treatment. Nomenclature of echinoid stereom morphology followed that of Smith (1980).

\subsection{Data analyses}

Data were evaluated for normality with the Shapiro-Wilk test (Shapiro \& Wilk 1965), which dictated the use of parametric or non-parametric statistics. For gross exams, percent weight loss from start and end of the experiment and mean gross lesion severity scores for all animals and time points were compared between treatment groups by 2-way ANOVA with treatment and color as factors. We chose to incorporate color into the analysis because orange $P$. ochraceus appeared more susceptible to developing gross lesions of SSWD in the field 


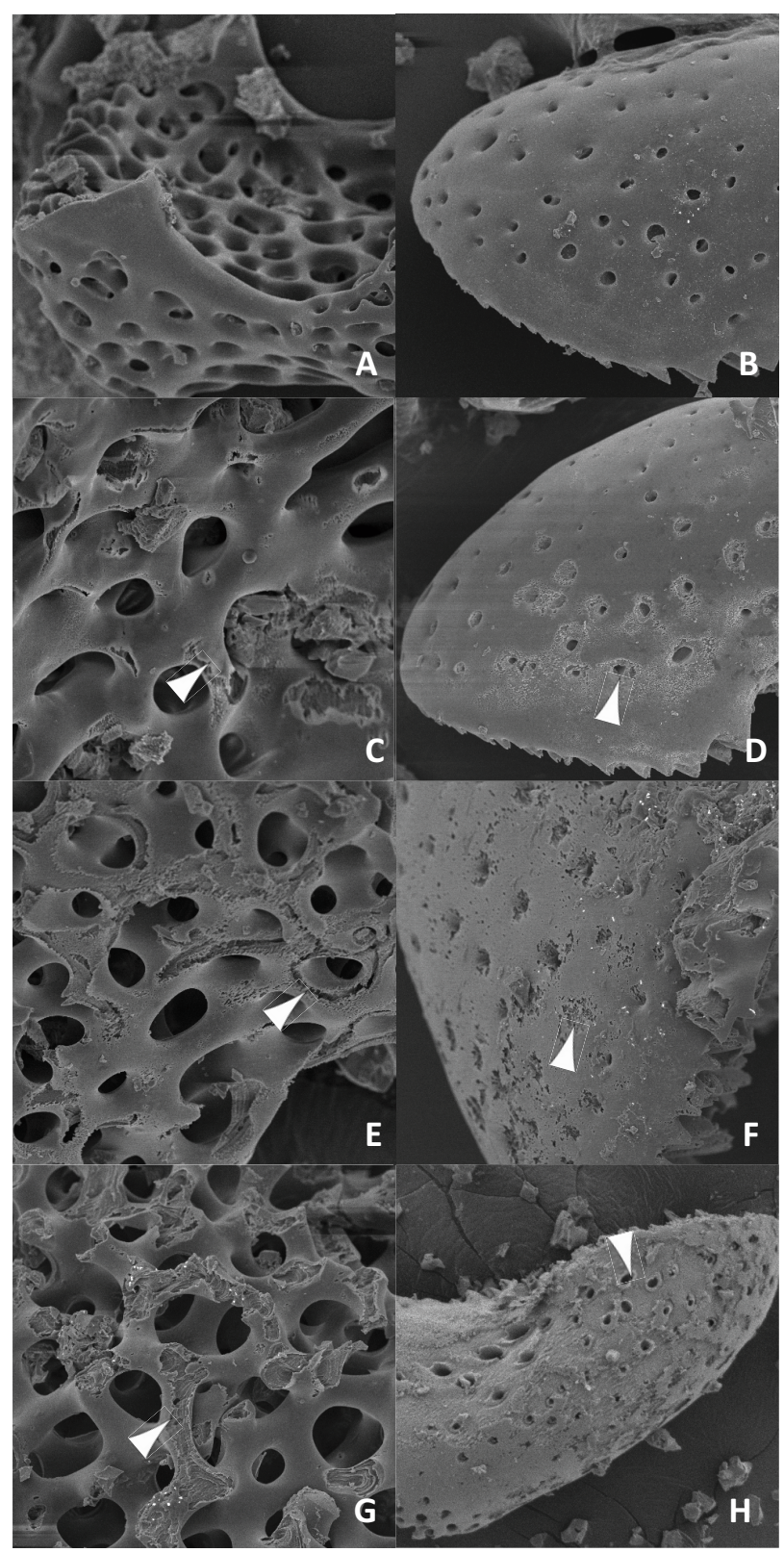

Fig. 3. Scanning electron microscopy of $(A, C, E, G)$ sellate ossicles and $(\mathrm{B}, \mathrm{D}, \mathrm{F}, \mathrm{H})$ abaxial surface of pedicellariae ossicles with no $(A, B)$, mild $(C, D)$, moderate $(E, F)$, and severe $(G, H)$ lesions. (A) Labyrinthic stereom with uniformly smooth surface of trabeculae. (B) Microperforate stereom with uniformly smooth surface containing variably sized pits with rounded edges. (C) Punctate to linear areas of surface erosion (arrow). (D) Areas of erosion mainly around the pits (arrow). (E) Linear erosions on the surface of trabeculae that have now coalesced to a serpiginous network (arrow). (F) In addition to erosion around pits, foci of erosion are in the imperforate portions of the stereom (arrow). (G) Marked erosion of trabeculae (arrow) with some instances of entire trabeculae missing (see concentric lamina above the letter ' $G$ ' indicating broken stump of trabecula). (H) Diffuse erosion of abaxial stereom revealing a rugose surface with intact walls around pits (arrow)
(Menge et al. 2016). In cases of significant differences, pairwise comparisons were made with $t$-tests using a Bonferroni adjustment of p-values to account for multiple tests (Rice 1989). We also plotted cumulative survivorship (Kaplan \& Meier 1958) and mean gross lesion scores of purple vs. orange morphs over time. For hematology, box plots of microscope field counts vs. treatment or lesion score for all animals and all time periods or simple presence/absence of lesions were examined. Based on the plot that appeared to show a difference (presence/absence of lesions), a Wilcoxon rank sum test was used to compare the 5 cell types (multinucleated, spindle, vibratile, stippled, spherule) between 2 sea stars with and without lesions with a Bonferroni adjustment of alpha (0.05/5 or 0.01). Phagocytes were not included, because they were not counted due to their overwhelming predominance in microscope fields (see Section 2.2). Histology lesion scores among the 4 treatment groups and gross lesion scores for all animals and time points were compared using 2-way ANOVA. In case of significant differences, post hoc comparisons were made as above. All analyses were done using R 3.5.3 (R Core Team 2017).

\section{RESULTS}

\subsection{Treatments and gross exams}

Nine orange and 11 purple sea stars were recruited into the study with $4,2,2$, and 3 purple and 1, 3, 3, and 2 orange sea stars in the control, peptone, Dunaliella, and POM treatments, respectively. Treatment $(F=8.8, \mathrm{p}=0.003)$ and color morph $(F=12.2$, $\mathrm{p}<0.0001$ ) had a significant effect on gross lesion severity scores but not on percent weight loss. Compared to controls, sea stars treated with peptone $(t=$ $\left.-5.9, \mathrm{p}=3 \times 10^{-8}\right)$, Dunaliella $(t=-3.1848, \mathrm{p}=0.002)$, or POM $\left(t=-6.6, \mathrm{p}=7 \times 10^{-10}\right)$ had significantly higher gross lesion scores, and orange sea stars had significantly higher $(t=3, \mathrm{p}=0.006)$ gross lesion scores than purple sea stars (Table 2). Compared to purple sea stars, orange sea stars survived longer (Fig. 4A) and had progressively higher gross lesion scores over time (Fig. 4B).

\subsection{Cytology of coelomic fluid}

Box plots of cell counts vs. treatment or severity score showed no clear differences, but those with lesions showed significantly elevated numbers of 
spindle cells $\left(W=325, \mathrm{p}=4 \times 10^{-5}\right)$ (Table 3). Cell morphology did not differ in sick vs. healthy sea stars save for the occasional diatom seen in the coelomic fluid of sick sea stars.

\subsection{Histology}

Apparently healthy sea star tissue comprised homogeneous MCT overlaid by cuboidal to columnar epidermis interspersed with muriform cells and appendages such as pedicellariae comprising ossicles connected by muscles overlaid by cuboidal to columnar epidermis (Fig. 5A). Normal ossicle morphology comprised a clear stereom (Fig. 5B) throughout which coursed a delicate meshwork of connective tissue with rare coelomocytes, the whole of which was indistinctly meshed with surrounding MCT (Fig. 5C). Early lesions in ossicles manifested as increased cellularity with loss of collagen fibers in the stereom (Fig. 5D,E). Collapse of stereom architecture led to isolated to coalescing cavities lined by coelomocytes (Fig. 5F,G) progressing to necrosis (Fig. 5H) and in some cases, complete ablation of ossicular architecture (Fig. 5I). Early lesions of
Table 2. Mean $\pm \mathrm{SD}$ (range) and $\mathrm{N}$ for percent weight loss and gross lesion scores (see Table 1) by treatment or color for 20 Pisaster ochraceus. Treatments are described in Section 2.1. Asterisks show scores significantly different for treatments vs. controls $\left({ }^{*}\right)$ and purple vs. orange morphs $\left({ }^{* *}\right)$. POM: particulate organic matter

\begin{tabular}{|lcccr|}
\hline & $\%$ Weight loss & N & Gross lesion score & N \\
\hline Treatment & & & & \\
Control & $-7 \pm 9(-18$ to 6$)$ & 5 & $0.64 \pm 0.92(0$ to 4$)$ & 77 \\
Peptone & $-14 \pm 7(-24$ to -4$)$ & 5 & $1.64 \pm 1.16(0 \text { to } 4)^{*}$ & 73 \\
Dunaliella & $-14 \pm 5(-22$ to -9$)$ & 5 & $1.23 \pm 1.25(0 \text { to } 4)^{*}$ & 65 \\
POM & $-13 \pm 9(-26$ to -2$)$ & 5 & $1.66 \pm 1(0 \text { to } 3)^{*}$ & 76 \\
Color & & & & \\
Purple & $-11 \pm 7(-24$ to 6$)$ & 9 & $1.11 \pm 1.07(0 \text { to } 4)^{* *}$ & 157 \\
Orange & $-14 \pm 8(-26$ to -2$)$ & 11 & $1.49 \pm 1.22(0$ to 4$)$ & 134 \\
\hline
\end{tabular}

Table 3. Mean $\pm \mathrm{SD}$ (range) of cells counted in 20 highpowered fields for 31 and 44 coelomic fluid samples from sea stars with and without gross lesions, respectively, partitioned by cell type. Asterisk indicates those counts differing significantly between groups

\begin{tabular}{|lcc|}
\hline Cell type & Gross lesion & No gross lesion \\
\hline Multinucleate & $6.1 \pm 16.3(0-103)$ & $9.8 \pm 18.6(0-81)$ \\
Spindle $^{*}$ & $3.5 \pm 20.9(0-139)$ & $0.9 \pm 2.1(0-8)$ \\
Stippled & $61.7 \pm 165.9(0-1049)$ & $0.9 \pm 2.6(0-13)$ \\
Vibratile & $0.8 \pm 2.5(0-15)$ & $4.9 \pm 11.6(0-47)$ \\
Spherule & $1.2 \pm 3.9(0-17)$ & 0 \\
\hline
\end{tabular}
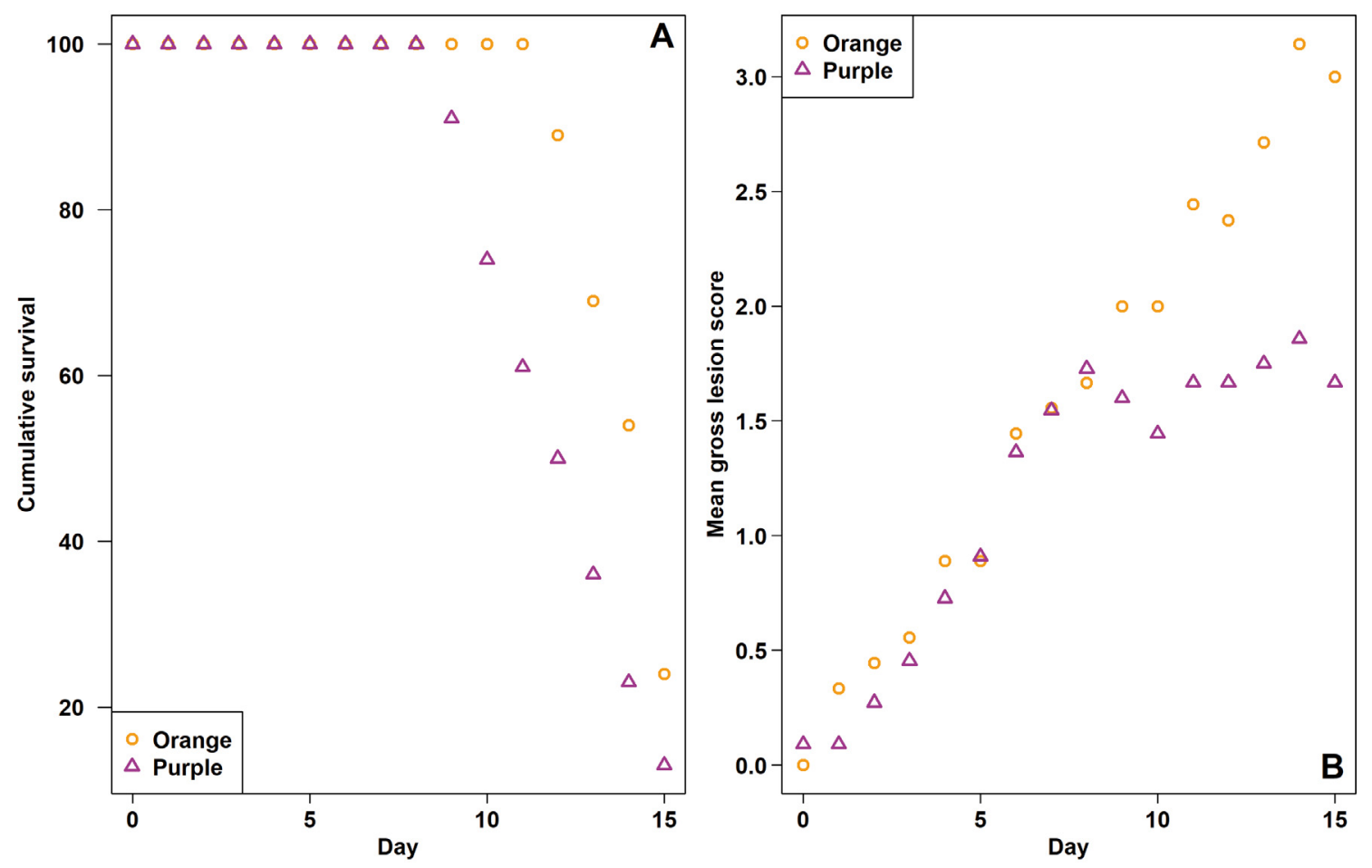

Fig. 4. Survivorship and gross lesions in Pisaster ochraceus. (A) Percent cumulative survivorship of orange and purple morphs over time. (B) Mean gross lesion score of orange and purple morphs over time 


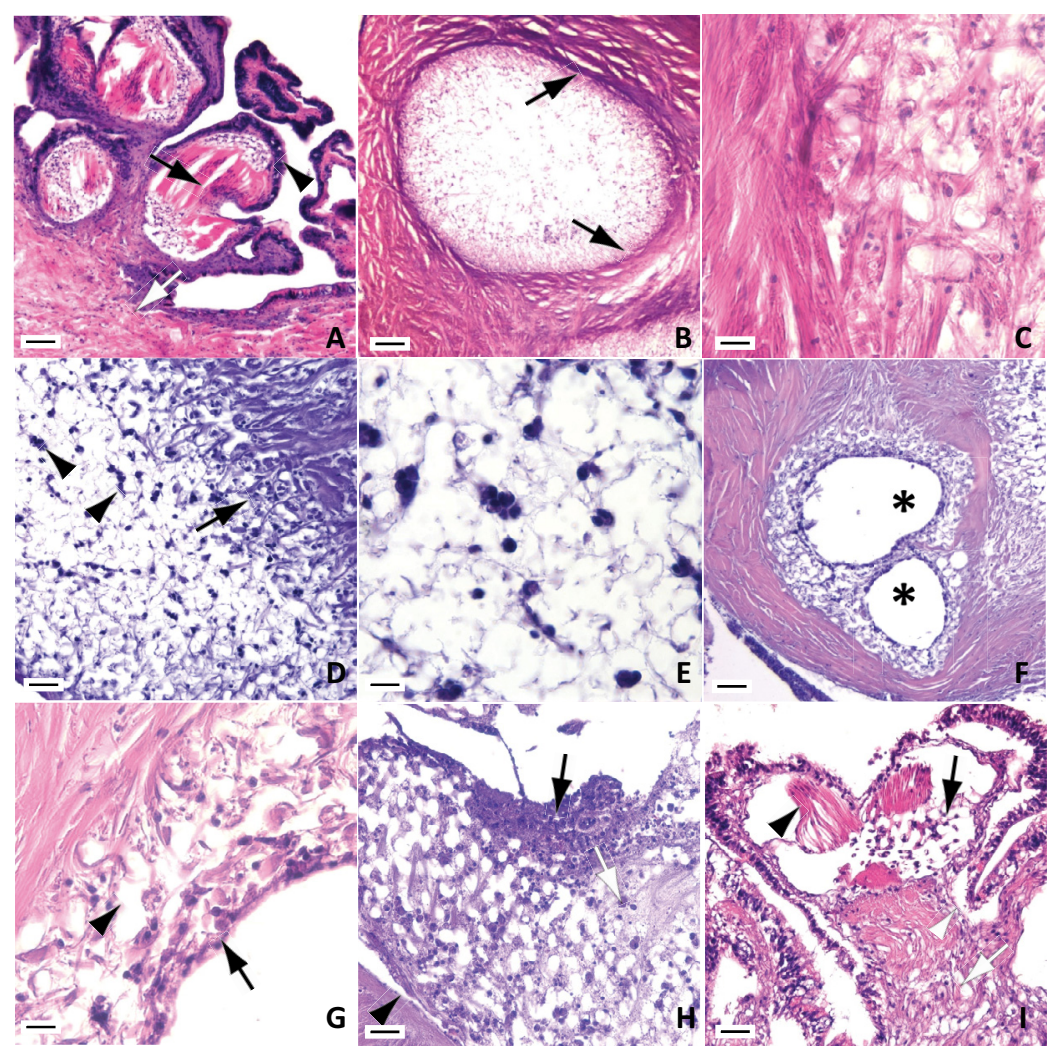

Fig. 5. Histology of (A-C) normal and (D-I) abnormal tissues of Pisaster ochraceus. (A) Pedicellariae with ossicles (white arrowhead), muscle (black arrow), epidermis (black arrowhead), and junction (white arrow) between mutable collagenous tissue (MCT; bottom) and epidermis. (B) Normal ossicle; note clear stereom interspersed with delicate trabeculae of connective tissue more prominent on the edges (arrows). (C) Close up of $\mathrm{B}_{i}$ note MCT to the left transitioning to the right as haphazardly arranged trabeculae of collagen and few cell nuclei infiltrating clear stereom. (D) Putative early inflammation of ossicle; note increased numbers of cells, some in clumps within stereom (arrowheads) and junction of ossicle to MCT (arrow). (E) Detail of D. (F) Lysis of ossicles; note large pleomorphic cavities $\left({ }^{*}\right)$ lined by coelomocytes. $(G)$ Detail of $F$; note collapse of stereom with aggregates of coelomocytes (arrow) lining lytic cavity and loss of collagen fibrils in stereom leading to clear spaces (arrowhead). (H) Necrosis of ossicles; note clumps of cell debris (black arrow) adjacent to lytic cavity, cellular infiltrates (white arrow), and detachment of MCT from ossicle (arrowhead). (I) Pedicellariae with muscle bundles (black arrowhead) suspended in clear space that used to be ossicle; note remnant stereom (black arrow), edematous MCT (white arrow), and clefting of epidermis (white arrowhead). Contrast this with A. Scale bars are $100 \mu \mathrm{m}(\mathrm{B}, \mathrm{F}), 50 \mu \mathrm{m}(\mathrm{A}, \mathrm{D}, \mathrm{H}, \mathrm{I})$, $25 \mu \mathrm{m}(\mathrm{C}, \mathrm{G})$, and $10 \mu \mathrm{m}(\mathrm{E})$

MCT included increased cellularity with occasional small clefting between epidermis (Fig. 6A) and MCT. Clefts seemed to expand and coalesce, leading to ulceration (Fig. 6B) concomitant with increased spacing between collagen fibrils of MCT (edema) (Fig 6C,D). In some cases, MCT appeared to be contracting away from epidermis, leaving filamentous processes (Fig. 6E). In more advanced lesions, there was massive disruption and necrosis of MCT (Fig. 6F).
Of 157 microscopic lesions seen in 15 sea stars, their frequency from most to least common included lysis of ossicles ( $24 \%$ or 37$)$, inflammation $(20 \%$ or 31$)$ or edema $(15 \%$ or 24$)$ of MCT, epidermal ulceration (14\% or 22$)$, subepidermal clefting between MCT and epidermis $(6 \%$ or 10$)$, ossicle hypercellularity, epidermal atrophy, epidermal hyperplasia $(3 \%$ each or $5,4,5)$, epidermal vacuolation, muriform cell depletion ( $2 \%$ or 3$)$ each, necrosis of coelomic lining, necrosis of muscle, subepidermal vacuolation, muriform cell hyperplasia $(1 \%$ each or $2,1,2,1)$. Histology scores differed significantly between treatments $(F=4.1, \mathrm{p}=0.01)$. Post hoc pairwise comparisons showed that histology lesion scores for Dunaliella treatment were significantly $(t=-2.4$, $\mathrm{p}=0.02$ ) higher than controls (Fig. 7A). Histology scores also differed significantly between gross lesion severity score categories $\left(F=8.4, \mathrm{p}=3 \times 10^{-5}\right)$. Post hoc pairwise comparisons showed that histology lesion scores for gross lesion severity scores $1(t=-3.3, \mathrm{p}=$ $0.007), 2(t=-3.3, p=0.005), 3(t=-4.8$, $\mathrm{p}=0.0003)$, and $4(t=-4.4, \mathrm{p}=0.001)$ were significantly higher than those for gross lesion severity score 0 (Fig. 7B). Overall, mean \pm SD histology lesion score for grossly normal $(2.5 \pm 2.9)$ was significantly lower than grossly lesioned $(7.1 \pm 3.3)$ biopsies $(t=-5.2, \mathrm{p}=$ $\left.4 \times 10^{-6}\right)$. At the microscopic level, all lesion types were seen in all treatments.

\subsection{Ossicles}

Four sea stars were processed for ossicle examination ( 1 for each treatment). Erosive lesions were seen in both sellate (Fig. 3A) and pedicellaria (Fig. 3B) ossicles. Those on sellate ossicles were seen on the surface of trabeculae and appeared to start as focal linear lesions (Fig. 3C) that eventually merged (Fig. 3E) and resulted in large serpiginous erosions (Fig. 3G). For pedicellariae, lesions appeared to originate around pits (Fig. 3D) that progressed to the smooth part of the stereom (Fig. 3F), with severe cases showing massive erosion leaving elevated pit walls (Fig. 3H). 


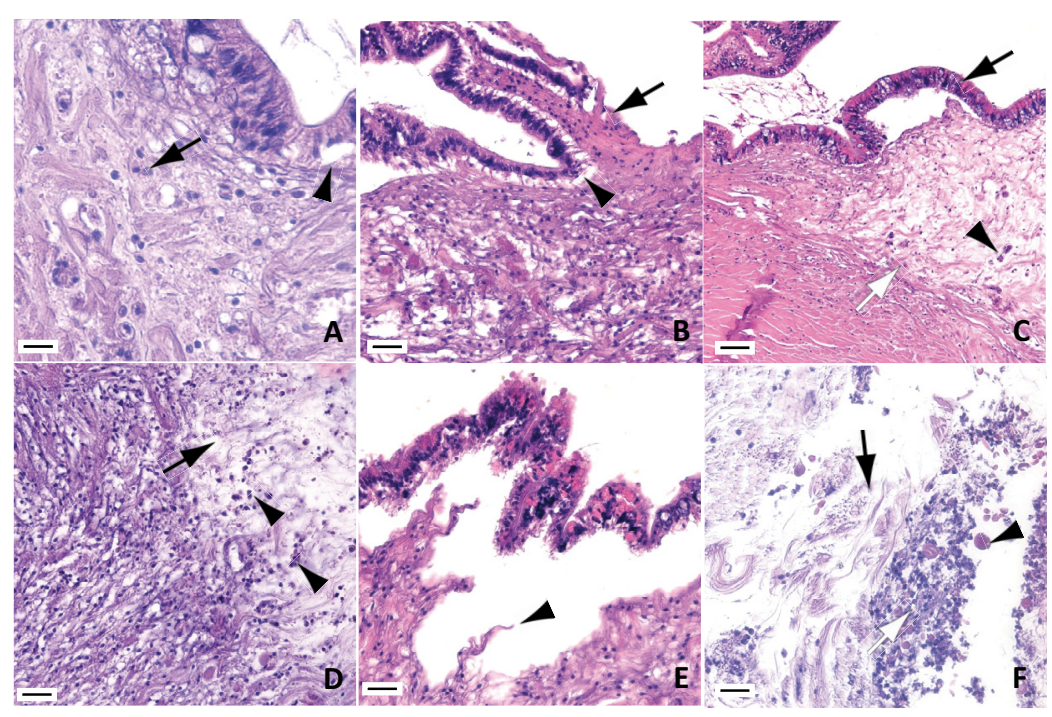

Fig. 6. Histology of mutable collagenous tissue (MCT) and epidermis in Pisaster ochraceus. (A) Increased cellularity (arrow) of MCT and localized clefting between MCT and epidermis (arrowhead). (B) Epidermal ulceration (black arrow) with MCT bereft of epidermis, vacuolation of MCT below epidermis (black arrowhead), and cleft formation (white arrow) overlying edematous MCT. (C) Cleft formation between underlying edematous MCT and epidermis (black arrow); note junction (white arrow) between normal and edematous MCT that contains clumps of necrotic debris (arrowhead). (D) Edema and inflammation of MCT; note more normal tissue to left and to the right, increased spaces between connective tissue fibrils (arrow), and infiltrates of coelomocytes (arrowheads). (E) Detail of cleft formation; note fimbriae of MCT (arrowhead). (F) Severe edema (black arrow) and necrosis (white arrow) of MCT with clumps of proteinaceous material (arrowhead). Scale bars are $25 \mu \mathrm{m}$ $(\mathrm{A}, \mathrm{D}-\mathrm{F}), 50 \mu \mathrm{m}(\mathrm{B}, \mathrm{C})$

\section{DISCUSSION}

The lesions and clinical progression seen here were grossly and microscopically indistinguishable from those described in wild sea stars with SSWD from the Atlantic (Bucci et al. 2017) and the Pacific (Hewson et al. 2014). This finding indicates that while SSWD is commonly assumed to be caused by an infectious agent (Fuess et al. 2015, Eisenlord et al. 2016, Aalto et al. 2020), non-infectious etiologies are equally possible, or this type of response is a non-specific sequela to general insults in this animal group. The animals used here originated from the wild, so it is possible that lesions could have originated from stress of captivity. Supporting this possibility is that control animals also developed lesions, albeit less severe but otherwise indistinguishable from the treatment groups. This invites a need to refine management of captive sea stars to reliably interpret experimental results and minimize the occurrence of gross and microscopic lesions. We saw no evidence that infectious agents were the cause of the lesions seen here, at least those visible at the light microscope level such as bacteria, parasites, or fungi. The sea stars were not fed during the $16 \mathrm{~d}$ of the study, and given that all animals lost weight over that time, it is tempting to conclude that starvation was at least in part responsible for the development of gross lesions. However, several experimental studies of starvation in sea stars have not reported lesions of SSWD, with effects of starvation limited to autolysis of pyloric ceca and shorten-
Fig. 7. Histology lesion scores for 20 Pisaster ochraceus. (A) Histology lesion score vs. treatment; asterisks indicate treatments significantly different $(\mathrm{p}<0.05)$ from each other. (B) Histology lesion score vs. gross lesion score; asterisk indicates value significantly different than the rest. Solid horizontal line is median, boxes bind $25^{\text {th }}$ and $75^{\text {th }}$ percentiles, and whiskers bind minimum and maximum
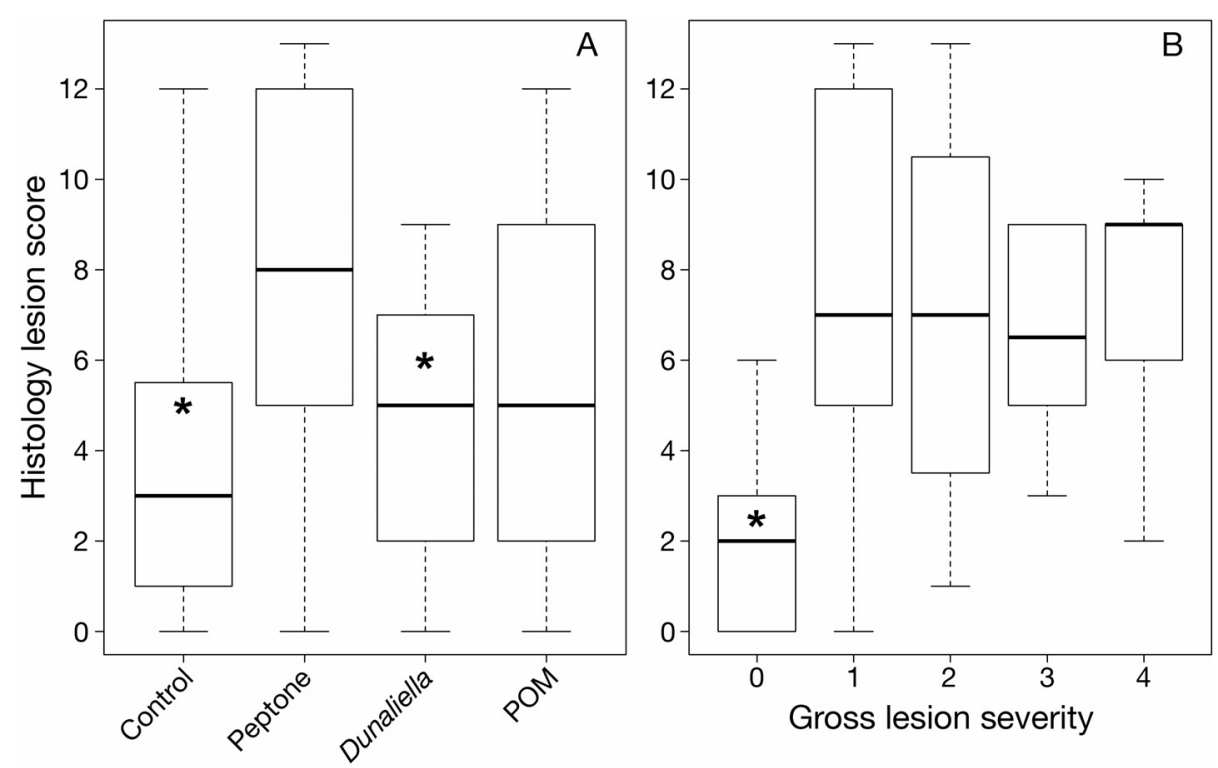
ing of rays (Hancock 1958, Lawrence 1971, Féral 1985, St-Pierre \& Gagnon 2015).

Our finding of orange Pisaster ochraceus developing more severe gross lesions of SSWD than purple individuals accorded with findings of Menge et al. (2016) in wild $P$. ochraceus in Oregon (USA) affected by SSWD; there, orange sea stars appeared disproportionately more affected by the disease even though they comprised only about $20 \%$ of the population (Raimondi et al. 2007). Based on our findings, it appears that orange sea stars not only developed more severe lesions but survived longer than purple sea stars. This has implications for field surveys in that lesioned orange sea stars with their ability to survive longer with more severe, and presumably more visible, lesions may be more readily visible in field surveys than purple sea stars, thereby introducing potential detection biases. Marking sea stars (Lamare et al. 2009) and monitoring them over time might provide valuable insights on important demographic parameters of disease such as species-specific case fatality rate. Color in $P$. ochraceus is thought to be driven mainly by diet (Fox \& Scheer 1941) rather than genetics (Harley et al. 2006). Differential susceptibility to disease based on color for marine invertebrates is not limited to sea stars. For instance, an analogous situation exists for corals in Hawaii. There, red phenotypes of Montipora capitata are more abundant than orange phenotypes, and red phenotypes are more likely to develop bleaching while orange phenotypes are more susceptible to tissue loss diseases, presumably due to host factors such as endogenous pigments or types of symbiotic algae (Shore-Maggio et al. 2018). Understanding the physiological mechanisms responsible for such differences might explain community assemblages of sessile marine invertebrates and the role of disease in population structures.

Hematological studies in sea stars appear uncommon. One recent study looking at sea star coelomic fluid relative to SSWD found electrolyte imbalances, but the authors were unable to effectively evaluate coelomocytes, probably in part due to finding too few cells in standard coelomic fluid smear preparations (Wahltinez et al. 2020). We found that concentrating the cells using syringe barrels (Moore 2017, Work et al. 2020b) allowed visualization and enumeration of cell types. The few studies that have looked at hematological responses of sea stars to insults involved responses to amputation. Pinsino et al. (2007) examined the hematological response of Asterias rubens to traumatic amputation and found modest increases of circulating coelomocytes in coelomic fluid and time-dependent expression of heat shock proteins. Silva \& Peck (2000) also found increased numbers of circulating coelomocytes after amputation in Odontaster validus. Although we did not do total coelomocyte counts, we, like Pinsino et al. (2007), also found that phagocytes comprised $>95 \%$ of cell populations in $P$. ochraceus. On wet mounts, Pinsino et al. (2007) identified macrophages, phagocytes, vibratile cells, and hemocytes in $A$. rubens. In the same species, Sharlaimova et al. (2014) used azure stains to document 7 types of coelomocytes, including small coelomocyte types 1 and 2, small and large petaloid agranulocytes, eosinophilic granulocytes, fusiform coelomocytes, and bi- or trinucleate cells. Pinsino et al. (2007) did not see a shift in relative populations of cells after amputation, whereas Sharlaimova et al. (2014) found a transient increase in the proportion of small circulating coelomocytes. An increase in spindle cells circulating in coelomic fluid of lesioned sea stars has not been documented before. Spindle-like cells have been seen in underlying coelomic epithelium in A. rubens (Gorshkov et al. 2009), and these cells are known to recruit to wound repair sites in the same sea star species (Ben Khadra et al. 2015a) and are apparently important in regeneration of muscle in asteroids (García-Arrarás \& Dolmatov 2010). Sorting out the origin and role of spindle cells in P. ochraceus might provide a tool to better understand host response to injuries and could be a potential marker of inflammation in this species. We ruled out the spindle structures as diatoms, because no characteristic refractile silica skeleton was seen on light microscopy.

Based on the frequency of occurrence of histological lesions, we suspect that the pathogenesis of epidermal ulceration in $P$. ochraceus starts with a combination of lysis of ossicles followed by or closely associated with inflammation of MCT and edema. This leads to a collapse of MCT, causing cleft formation between MCT and epidermis, with eventual sloughing and ulceration of the epidermis (Fig. 2). The changes seen here have similarities and differences from simple wound repair, a process that has been well characterized in sea stars and that consists of an orderly progression of repair, early, and advanced regenerative phases (Candia Carnevali 2006, Ben Khadra et al. 2015a,b, 2017, 2018, Ferrario et al. 2018). In repair, there is contraction of MCT to close off the wound with edema and inflammation of MCT, clot formation, and re-epithelialization that occurs from the edge of the wound. Early regeneration involves genesis of organs such as water vascular canals and nervous tissues. Late regeneration in- 
volves formation of tube feet and other adnexa. Our comparisons to these studies were limited, because examinations of tissues were constrained to $4 \mathrm{~mm}$ biopsies, whereas wound repair studies involved examination of entire rays. However, inflammation and edema of MCT were a commonality we saw with wound repair. In contrast, ossicle lysis, contraction of MCT with cleft formation, and epidermal ulceration have not been described in wound repair, nor did we see clot formation or centripetal re-epithelialization (Ferrario et al. 2018). Our pathology findings fit with a model of loss of turgor with collapse of MCT and ossicles, followed by epidermal ulceration seen in field outbreaks of SSWD in California in 1999 (Eckert et al. 2000). Given the importance of the nervous system in mediating stiffness of MCT (Motokawa 2011), perhaps SSWD is an uncontrolled form of autotomy originating in neuronal dysfunction, and understanding parallels or differences of autotomy vs. SSWD at the cellular level might shed further light on the pathogenesis of SSWD. Collapse of the body wall would also fit with metatranscriptomic analyses of SSWD in Pycnopodia helianthoides, which showed decreases in expression of genes associated with cytoskeletal integrity and tissue remodeling (Gudenkauf \& Hewson 2015).

Lysis of ossicles associated with coelomocyte infiltrates was a signal feature of experimentally induced SSWD. This has not been described in histological examinations of wound repair in other sea stars, including A. rubens (Ben Khadra et al. 2015b) Leptasterias hexactis (Mladenov et al. 1989), A. rollestoni (Fan et al. 2011), Amphiura filiformis and Echinaster sepositus (Ferrario et al. 2018), Antedon mediterranea (Candia Carnevali et al. 1995), or Odontaster validus (Núñez-Pons et al. 2018), where, as in our study, tissues were decalcified with EDTA prior to processing for histology. Lysis of ossicles was reported in wild sea stars with epidermal ulceration from the Atlantic (Bucci et al. 2017) but not in those from the Pacific (Newton \& Smolowitz 2018). In the case of Atlantic sea stars, lysis of ossicles was noted in both normal and lesioned sea stars, with the latter having more severe inflammation, and the authors were unclear about the role that decalcification could play in the lysis of ossicles in normal sea stars (Bucci et al. 2017). We doubt that the lesions seen here were an artefact of tissue processing. However, to confirm this, we looked at ossicles that were not decalcified and showed a range of lesions by electron microscopy (Fig. 3), again suggesting that our findings were not a processing artefact. What prompts these ossicle lesions is unclear; however, the presence of cellular infiltrates indicates that inflammation could play a role. For example, urchins have calcite phagocytizing cells that remodel ossicles during spine formation (Märkel \& Röser 1983a,b). Holland \& Grimmer (1981) examined syzygies (specific areas where arms autotomize) in the crinoid Florometra serratissima, and showed, via scanning electron microscopy, areas of lysis in ossicles very similar to the mild ossicular lesions seen here (Fig. 3C). The initiation of lytic lesions near perforations in the stereom (where tissues and cells are located) in pedicellariae of $P$. ochraceus seen here was intriguing and might, along with histology, indicate that cellular reabsorption processes are responsible for ossicle lesions. Understanding the cell types responsible for this would be important.

In summary, within the constraints herein, SSWD in $P$. ochraceus appears to be a basal-to-tissue surface process starting with the collapse of ossicles and $\mathrm{MCT}$, leading to epidermal ulceration and visible clinical signs of wasting that appears to affect orange morphs more severely than purple morphs. Given the similarity of gross lesions among different species of sea stars and regions, it is likely that, like other animals, sea stars have a limited host response repertoire when it comes to manifestation of gross lesions. There is thus a clear need to use additional tools like microscopic and clinical pathology to better refine case definitions of SSWD, because like other animals, clinical manifestation of SSWD in sea stars will likely differ between species and potentially regions. A reasonable analogy is fibropapillomatosis, a tumor disease of green turtles Chelonia mydas that has different pathologic (Work et al. 2004) and immunologic (Work et al. 2020a) manifestations between the Pacific and Atlantic. Careful examination of sick sea stars at the cellular level could go a long way towards illuminating the causes of SSWD and the genesis of management interventions to stem disease in this ecologically important group of animals.

Data availability. Data associated with this article are available at https://doi.org/10.5066/P9LGH5ZF.

Acknowledgements. Any use of trade, firm, or product names is for descriptive purposes only and does not imply endorsement by the US Government. We thank Karl Menard and the staff at the Bodega Bay Marine Lab (University of California, Davis) for assistance with sample collection, and anonymous reviewers for providing constructive comments.

\section{LITERATURE CITED}

Aalto EA, Lafferty KD, Sokolow SH, Grewelle RE and others (2020) Models with environmental drivers offer a plausible mechanism for the rapid spread of infectious disease 
outbreaks in marine organisms. Sci Rep 10:5975

Aquino CA, Besemer RM, DeRito CM, Kocian J and others (2021) Evidence that microorganisms at the animalwater interface drive sea star wasting disease. Front Microbiol 11:3278

Bandín I, Dopazo CP (2011) Host range, host specificity and hypothesized host shift events among viruses of lower vertebrates. Vet Res 42:67

Bates AE, Hilton BJ, Harley CDG (2009) Effects of temperature, season and locality on wasting disease in the keystone predatory sea star Pisaster ochraceus. Dis Aquat Org 86:245-251

Ben Khadra Y, Ferrario C, Di Benedetto C, Said K, Bonasoro F, Carnevali MD, Sugni M (2015a) Re-growth, morphogenesis, and differentiation during starfish arm regeneration. Wound Repair Regen 23:623-634

Ben Khadra Y, Ferrario C, Di Benedetto C, Said K, Bonasoro F, Carnevali MD, Sugni M (2015b) Wound repair during arm regeneration in the red starfish Echinaster sepositus. Wound Repair Regen 23:611-622

Ben Khadra Y, Sugni M, Ferrario C, Bonasoro F, Varela Coelho A, Martinez P, Candia Carnevali MD (2017) An integrated view of asteroid regeneration: tissues, cells and molecules. Cell Tissue Res 370:13-28

Ben Khadra Y, Sugni M, Ferrario C, Bonasoro F, Oliveri P, Martinez P, Candia Carnevali MD (2018) Regeneration in stellate echinoderms: Crinoidea, Asteroidea and Ophiuroidea. In: Kloc M, Kubiak JZ (eds) Marine organisms as model systems in biology and medicine. Springer International Publishing, Cham, p 285-320

Boolootian R, Giese A (1958) Coelomic corpuscles of the echinoderms. Biol Bull (Woods Hole) 115:53-63

Bucci C, Francoeur M, McGreal J, Smolowitz R, ZazuetaNovoa V, Wessel GM, Gomez-Chiarri M (2017) Sea star wasting disease in Asterias forbesi along the Atlantic coast of North America. PLOS ONE 12:e0188523

Candia Carnevali MD (2006) Regeneration in echinoderms: repair, regrowth, cloning. Invertebr Surviv J 3:64-76

Candia Carnevali MD, Bonasoro F, Lucca E, Thorndyke MC (1995) Pattern of cell proliferation in the early stages of arm regeneration in the feather star Antedon mediterranea. J Exp Zool 272:464-474

Eckert GL, Engle JM, Kushner DJ (2000) Sea star disease and population declines at the Channel Islands. In: Proc $5^{\text {th }}$ California Island Symposium, February 2000. US Department of the Interior, Minerals Management Service, Camarillo, CA, p 390-393

Eisenlord ME, Groner ML, Yoshioka RM, Elliott J and others (2016) Ochre star mortality during the 2014 wasting disease epizootic: role of population size structure and temperature. Philos Trans R Soc B 371:20150212

Fan T, Fan X, Du Y, Sun W, Zhang S, Li J (2011) Patterns and cellular mechanisms of arm regeneration in adult starfish Asterias rollestoni Bell. J Ocean Univ China 10:255

F Féral JP (1985) Effect of short-term starvation on the biochemical composition of the apodous holothurian Leptosynapta galliennei (Echinodermata): possible role of dissolved organic material as an energy source. Mar Biol 86:297-306

Ferrario C, Ben Khadra Y, Czarkwiani A, Zakrzewski A and others (2018) Fundamental aspects of arm repair phase in two echinoderm models. Dev Biol 433:297-309

Fox DL, Scheer BT (1941) Comparative studies of the pigments of some Pacific coast echinoderms. Biol Bull (Woods Hole) 80:441-455
Fuess LE, Eisenlord ME, Closek CJ, Tracy AM and others (2015) Up in arms: immune and nervous system response to sea star wasting disease. PLOS ONE 10:e0133053

* García-Arrarás JE, Dolmatov IY (2010) Echinoderms: potential model systems for studies on muscle regeneration. Curr Pharm Des 16:942-955

KGorshkov AN, Blinova MI, Pinaev GP (2009) Ultrastructure of coelomic epithelium and coelomocytes of the starfish Asterias rubens L. in norm and after wounding. Cell Tissue Biol 3:477

Gudenkauf BM, Hewson I (2015) Metatranscriptomic analysis of Pycnopodia helianthoides (Asteroidea) affected by sea star wasting disease. PLOS ONE 10:e0128150

*Hancock DA (1958) Notes on starfish on an Essex oyster bed. J Mar Biol Assoc UK 37:565-589

* Harley CDG, Pankey MS, Wares JP, Grosberg RK, Wonham MJ (2006) Color polymorphism and genetic structure in the sea star Pisaster ochraceus. Biol Bull (Woods Hole) 211:248-262

* Hewson I, Button JB, Gudenkauf BM, Miner B and others (2014) Densovirus associated with sea-star wasting disease and mass mortality. Proc Natl Acad Sci USA 111: 17278-17283

*Hewson I, Bistolas KSI, Quijano Cardé EM, Button JB and others (2018) Investigating the complex association between viral ecology, environment, and Northeast Pacific sea star wasting. Front Mar Sci 5:77

* Hewson I, Aquino CA, DeRito CM (2020) Virome variation during sea star wasting disease progression in Pisaster ochraceus (Asteroidea, Echinodermata). Viruses 12:1332

Holland ND, Grimmer JC (1981) Fine structure of syzygial articulations before and after arm autotomy in Florometra serratissima (Echinodermata: Crinoidea). Zoomorphology 98:169-183

Hyman LH (1955) The invertebrates: Echinodermata, Vol 4. McGraw Hill, New York, NY

* Jackson EW, Pepe-Ranney C, Johnson MR, Distel DL, Hewson I (2020a) A highly prevalent and pervasive densovirus discovered among sea stars from the North American Atlantic coast. Appl Environ Microbiol 86:e02723-19

* Jackson EW, Wilhelm RC, Johnson MR, Lutz HL and others (2020b) Diversity of sea star-associated densoviruses and transcribed endogenized viral elements of densovirus origin. J Virol 95:e01594-20

Jaffe N, Eberl R, Bucholz J, Cohen CS (2019) Sea star wasting disease demography and etiology in the brooding sea star Leptasterias spp. PLOS ONE 14:e0225248

Kaplan EL, Meier P (1958) Nonparametric estimation from incomplete observations. J Am Stat Assoc 53:457-481

*Kay SWC, Gehman ALM, Harley CDG (2019) Reciprocal abundance shifts of the intertidal sea stars, Evasterias troschelii and Pisaster ochraceus, following sea star wasting disease. Proc R Soc B 286:20182766

Kohl WT, McClure TI, Miner BG (2016) Decreased temperature facilitates short-term sea star wasting disease survival in the keystone intertidal sea star Pisaster ochraceus. PLOS ONE 11:e0153670

Konar B, Mitchell TJ, Iken K, Coletti H and others (2019) Wasting disease and static environmental variables drive sea star assemblages in the northern Gulf of Alaska. J Exp Mar Biol Ecol 520:151209

* Lamare MD, Channon T, Cornelisen C, Clarke M (2009) Archival electronic tagging of a predatory sea startesting a new technique to study movement at the individual level. J Exp Mar Biol Ecol 373:1-10 
Lawrence JM (1971) Effect of starvation on the organic nutrient reserves in the test of Tripneustes gratula [sic] (L.) (Echinodermata: Echinoidea) from the Gulf of Elat. Isr J Zool 20:249-251

Märkel K, Röser U (1983a) Calcite-resorption in the spine of the echinoid Eucidaris tribuloides. Zoomorphology 103: 43-58

Märkel K, Röser U (1983b) The spine tissues in the echinoid Eucidaris tribuloides. Zoomorphology 103:25-41

* Menge BA, Cerny-Chipman EB, Johnson A, Sullivan J, Gravem S, Chan F (2016) Sea star wasting disease in the keystone predator Pisaster ochraceus in Oregon: insights into differential population impacts, recovery, predation rate, and temperature effects from long-term research. PLOS ONE 11:e0153994

Miner CM, Burnaford JL, Ambrose RF, Antrim L and others (2018) Large-scale impacts of sea star wasting disease (SSWD) on intertidal sea stars and implications for recovery. PLOS ONE 13:e0192870

Mladenov PV, Bisgrove B, Asotra S, Burke RD (1989) Mechanisms of arm-tip regeneration in the sea star, Leptasterias hexactis. Rouxs Arch Dev Biol 198:19-28

Moebus K (1980) A method for the detection of bacteriophages from ocean water. Helgol Meeresunters 34:1-14

Montecino-Latorre D, Eisenlord ME, Turner M, Yoshioka R and others (2016) Devastating transboundary impacts of sea star wasting disease on subtidal asteroids. PLOS ONE 11:e0163190

Moore AR (2017) Preparation of cytology samples: tricks of the trade. Vet Clin North Am Small Anim Pract 47:1-16

Motokawa T (2011) Mechanical mutability in connective tissue of starfish body wall. Biol Bull (Woods Hole) 221: 280-289

Newton AL, Smolowitz R (2018) Invertebrates. In: Terio KA, McAloose D, Leger JS (eds) Pathology of wildlife and zoo animals. Academic Press, London, p 1019-1052

Núñez-Pons L, Work TM, Angulo-Preckler C, Moles J, Avila C (2018) Exploring the pathology of an epidermal disease affecting a circum-Antarctic sea star. Sci Rep 8:11353

Pinsino A, Thorndyke MC, Matranga V (2007) Coelomocytes and post-traumatic response in the common sea star Asterias rubens. Cell Stress Chaperones 12:331-341

Prophet EB, Mills B, Arrington JB, Sobin LH (1992) Laboratory methods in histotechnology, Armed Forces Institute of Pathology, Washington, DC

R Core Team (2017) R: a language and environment for statistical computing. R Foundation for Statistical Computing, Vienna

Raimondi PT, Sagarin RD, Ambrose RF, Bell C and others (2007) Consistent frequency of color morphs in the sea star Pisaster ochraceus (Echinodermata: Asteriidae) across open-coast habitats in the northeastern Pacific. Pac Sci 61:201-210

Rice WR (1989) Analyzing tables of statistical tests. Evolution 43:223-225

Editorial responsibility: Esther Peters,

Fairfax, Virginia, USA

Reviewed by: 3 anonymous referees
Schultz JA, Cloutier RN, Côté IM (2016) Evidence for a trophic cascade on rocky reefs following sea star mass mortality in British Columbia. PeerJ 4:e1980

Shapiro SS, Wilk MB (1965) An analysis of variance test for normality (complete samples). Biometrika 52:591-611

* Sharlaimova NS, Pinaev GP, Petukhova OA (2010) Comparative analysis of behavior and proliferative activity in culture of cells of coelomic fluid and of cells of various tissues of the sea star Asterias rubens L. isolated from normal and injured animals. Cell Tissue Biol 4:280-288

Sharlaimova N, Shabelnikov S, Petukhova O (2014) Small coelomic epithelial cells of the starfish Asterias rubens L. that are able to proliferate in vivo and in vitro. Cell Tissue Res 356:83-95

Shore-Maggio A, Callahan SM, Aeby GS (2018) Trade-offs in disease and bleaching susceptibility among two color morphs of the Hawaiian reef coral, Montipora capitata. Coral Reefs 37:507-517

* Silva J, Peck L (2000) Induced in vitro phagocytosis of the Antarctic starfish Odontaster validus (Koehler 1906) at $0^{\circ} \mathrm{C}$. Polar Biol 23:225-230

Smith AB (1980) Stereom microstructure of the echinoid test. Spec Pap Palaeontol 25:1-81

* St-Pierre AP, Gagnon P (2015) Effects of temperature, body size, and starvation on feeding in a major echinoderm predator. Mar Biol 162:1125-1135

*Wahltinez SJ, Newton AL, Harms CA, Lahner LL, Stacy NI (2020) Coelomic fluid evaluation in Pisaster ochraceus affected by sea star wasting syndrome: evidence of osmodysregulation, calcium homeostasis derangement, and coelomocyte responses. Front Vet Sci 7:131

Work T, Meteyer C (2014) To understand coral disease, look at coral cells. EcoHealth 11:610-618

*Work TM, Balazs GH, Rameyer RA, Morris RA (2004) Retrospective pathology survey of green turtles Chelonia mydas with fibropapillomatosis from the Hawaiian Islands, 1993-2003. Dis Aquat Org 62:163-176

Work TM, Russell R, Aeby GS (2012) Tissue loss (white syndrome) in the coral Montipora capitata is a dynamic disease with multiple host responses and potential causes. Proc R Soc B 279:4334-4341

Work TM, Dagenais J, Willimann A, Balazs G, Mansfield K, Ackermann M (2020a) Differences in antibody responses against Chelonid alphaherpesvirus 5 (ChHV5) suggest differences in virus biology in ChHV5-seropositive green turtles from Hawaii and ChHV5-seropositive green turtles from Florida. J Virol 94:e01658-19

* Work TM, Millard E, Mariani DB, Weatherby TM and others (2020b) Cytology reveals diverse cell morphotypes and cell-in-cell interactions in normal collector sea urchins Tripneustes gratilla. Dis Aquat Org 142:63-73

Famada A, Tamori M, Iketani T, Oiwa K, Motokawa T (2010) A novel stiffening factor inducing the stiffest state of holothurian catch connective tissue. J Exp Biol 213: 3416-3422

Submitted: October 28, 2020

Accepted: March 17, 2021

Proofs received from author(s): May 28, 2021 